\title{
PENDIDIKAN YANG MEMANUSIAKAN MANUSIA
}

\author{
Esther Christiana \\ Character Building Development Center, BINUS University \\ Jln. Kemanggisan Ilir III No. 45, Kemanggisan-Palmerah, Jakarta Barat 11480 \\ estherchristiana@yahoo.co.id
}

\begin{abstract}
Education helps people to perfect her/himself as a human being. Education and being human is an integral part, regardless of what the goal or hope for the future. Humanity becomes an important part of the mission of education. Humans are creatures who have special abilities. All things humans do come from natural gift, perfect gift of the Creator in the form of body, soul, mind, and feelings. The perfection of a human is in the nature of humanity, not in his/her efforts but rather as the Creator's gift. Human perfection in human dimension exists in human imperfection. The perfection in imperfect body is that it has weaknesses, can feel pain, has the ability and endurance limits. The perfection in vibrant soul is that it is full of passion and fragile and may die prematurely. The perfection in feelings is that it can be angry, sad, disappointed, excited. The perfection in mind is that it can think of things that constructs and ruins, creates and destroys. Education plays roles in human choices, the destruction/development of human, which destroys or builds, which kills or gives life, which creates or destroys. The education that humanizes human is the education of humanity-oriented with the education model developing for the space dimension of the development of humanity towards the highest manifestations of each dimension, space of freedom, and space for personal reflection or group.
\end{abstract}

Keywords: education, humanity, space of freedom, space of reflection

\begin{abstract}
ABSTRAK
Pendidikan membantu manusia menyempurnakan dirinya sebagai manusia. Pendidikan dan menjadi manusia adalah satu bagian yang tak terpisahkan, terlepas dari apa yang menjadi cita-cita atau harapan masa depan. Kemanusiaan menjadi bagian penting misi penididikan. Manusia adalah makluk yang memiliki kemampuan istimewa. Semua hal yang dapat dilakukan manusia berasal dari anugerah kodrati, pemberian sempurna Sang Pencipta dalam bentuk tubuh, jiwa, pikiran, dan perasaan. Kesempurnaan manusia ada dalam kodrat kemanusiaannya, bukan atas usaha manusianya melainkan sebagai anugerah Pencipta. Kesempurnaan manusia dalam dimensi kemanusiaannya itu eksis di dalam ketidaksempurnaan manusia. Kesempurnaan dalam tubuh yang tidak sempurna, memiliki kelemahan, dapat merasakan sakit, memiliki batas kemampuan dan daya tahan. Kesempurnaan dalam jiwa yang bersemangat penuh gairah dan juga rapuh yang mungkin mati sebelum waktunya. Kesempurnaan dalam perasaan yang dapat marah, sedih, kecewa, gembira. Kesempurnaan dalam pikiran yang dapat memikirkan hal yang membangun dan merusak, pikiran yang mencipta dan menghancurkan. Pendidikan berperan dalam pilihan-pilihan manusia, yaitu kehancuran atau pengembangan kemanusiaan, yang merusak atau membangun, yang mematikan atau memberi kehidupan, yang mencipta atau menghancurkan. Pendidikan yang memanusiakan manusia adalah pendidikan yang berorientasi pada kemanusiaan manusia dengan model pendidikan yang mengembangkan ruang bagi pengembangan dimensi kemanusiaan ke arah perwujudan tertinggi dari pengembangan tiap dimensi, ruang kebebasan, dan ruang bagi refleksi pribadi atau kelompok.
\end{abstract}

Kata kunci: pendidikan, kemanusiaan manusia, ruang kebebasan, ruang refleksi 


\section{PENDAHULUAN}

Wawancara salah seorang penyiar televisi swasta dengan seseorang asli suku Baduy, yang diterjemahkan dari bahasa Sunda, kurang lebih sebagai berikut: "Apa untungnya sekolah? Apabila anak sekolah, nanti jadi pintar. Orang pintar cenderung membodohi/menipu orang. Jadi, untuk apa sekolah kalau nantinya menjadi orang yang membodohi orang lain?” Pendapatnya menyadarkan kita akan arti penting kata kemanusiaan dalam tujuan sebuah pendidikan. Alasan masyarakat Baduy menjadi masuk akal jika pendidikan hanya mendidik anak pintar, kreatif, banyak pengetahuan, pandai mencari uang alias seorang entrepreneur handal, namun tak mampu mengangkat sisi kemanusiaan dirinya sendiri apalagi orang lain. Apa gunanya menjadi orang yang katanya terdidik namun sisi kemanusiaannya merosot, dan hanya merugikan orang lain?

Kemanusiaan yang menjadi bagian penting misi pendidikan. Brook mengutip JohnDewey (Brook \& brook, 1993:9) yang menentang pemikiran bahwa pendidikan adalah untuk mempersiapkan masa depan. Sebaliknya, Dewey berpendapat bahwa belajar/pendidikan adalah bagian dari kehidupan itu sendiri dan bukan untuk mempersiapkan masa depan. Menurut Dewey: "education be viewed as process of living and not preparation for future living". Pendapat Dewey dapat ditafsir bahwa pendidikan adalah proses yang membantu perkembangan manusia atau dengan kata lain memanusiakan manusia. Pendidikan membantu manusia menyempurnakan dirinya sebagai manusia.

Pendapat Dewey ini tidak serta merta mengabaikan masa depan. Apabila ditelusuri dengan seksama maka secara tidak langsung, pendidikan juga berpengaruh pada masa depan nara didik. Bukankah manusia yang senantiasa menyempurnakan dirinya itu melalui proses belajar atau yang disebut para filsuf, penyempurnaan melalui kegiatan imanem dan kegiatan transitif (Louis, 1984:37) ini yang menjadi pemilik masa depan? Artinya, nara didik akan membentuk masa depannya sendiri melalui proses penyempurnaannya, antara lain melalui pendidikan dan proses belajar. Pendapat Dewey ini ingin mengedepankan yang utama, yaitu pendidikan pertama-tama tidak semata-mata ditujukan demi masa depan tetapi demi kemanusiaan manusia itu sendiri.

Pendidikan dan menjadi manusia adalah satu bagian yang tak terpisahkan, terlepas dari apa yang menjadi cita-cita atau harapan masa depan. Keterikatan ini menunjukkan bahwa idealnya, pendidikan berorientasi pada kemanusiaan manusia. Masalahnya, apakah lembaga-lembaga pendidikan yang telah mewarnai misinya dengan kemanusiaan itu telah memberikan fasilitas yang memadai melalui proses pendidikan bagi pengembangan kemanusiaan manusia atau hanya untuk persiapan masa depan? Sehingga misi kemanusiaan itu hanya menjadi semboyan belaka.

See Ching Mey dan Lee Siew Siew melalui Pusat Pengajian Ilmu Pendidikan, Universiti Sains Malaysia, menemukan $43.41 \%$ daripada sampel pelajar yang mengalami kemurungan klinikal yang berpotensi melakukan usaha bunuh diri. Ironisnya lagi, kemurungan remaja berhubungan dengan tahap pencapaian akademik lemah. Data ini menunjukkan bahwa pendidikan cenderung mengejar prestasi akademik demi persiapan masa depan dan melupakan kemanusiaan manusianya sendiri (http://myais.fsktm.um.edu.my/6578/1/JPPSee (113-129)B.pdf, 26 Agustus 2012). Sirnanya kemanusiaan ditunjukkan melalui usaha manusia untuk bunuh diri. Manusia berusaha bunuh diri karena ia tak mampu lagi melihat kesempurnaan di dalam diri kemanusiaannya. Ia hanya melihat satu pilihan, yaitu bunuh diri dan ia bertindak untuk bunuh diri dalam rangka menunjukkan sisa kemanusiaan yang sebenarnya tak dirasakannya lagi. Sangat mengejutkan, data bunuh diri per 100.000 orang yang digambarkan pada gambar 1 memperlihatkan bahwa pendidikan gagal membuat manusia menemukan kemanusiaannya karena negara-negara dengan angka bunuh diri tertinggi justru bukanlah negara terpencil dan terbelakang namun dari negara-negara maju termasuk negara Finlandia, yang termasuk dalam negara dengan sistem pendidikan termaju. 


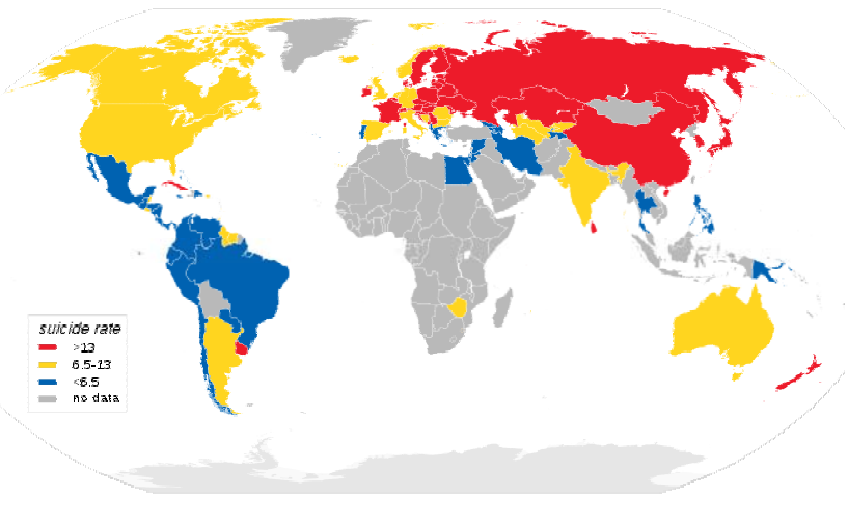

Gambar 1 Gambaran Manusia yang Bunuh Diri per 100.000 orang

(Wikipedia, 2012)

Idealnya, negara-negara dengan sistem pendidikan modern, baik muatan, strategi pembelajaran, dan gaya mengajar yang modern di kelas/luar kelas menunjukkan manusia-manusia yang menemukan, mengembangkan, dan menunjukkan kemanusiaan. Namun, melalui data orang yang bunuh diri, hasilnya tidak sesuai dengan yang ideal, yaitu makin modern pendidikan, makin tidak menjauhkan manusia dari keadaan frustasi dan berakhir dengan bunuh diri. Data ini menunjukkan juga bahwa pendidikan modern tidak menjamin mengantarkan manusia pada pengembangan kemanusiaannya. Hal ini sangat bergantung pada orientasi pendidikan itu sendiri. Apakah pendidikan beorientasi pada pengembangan kemanusiaan manusia atau hanya sekadar mempersiapkan masa depan, dapat hidup nyaman, berkarier, dan menghasilkan banyak uang. Di Indonesia, diperoleh data bahwa dari tahun 2003 hingga tahun 2011, terjadi penurunan angka buta huruf untuk anak usia 15 tahun dari angka 10.21 di tahun 2003 menurun 7.17 pada 2011 (BPS, 2011). Angka ini menunjukkan semakin banyak anak usia 15 tahun yang mengenyam pendidikan. Idealnya, jika pendidikan itu bukan sekadar mengajarkan pengetahuan, tetapi juga mengembangkan kemanusiaan manusia, maka kasus bunuh diri usia remaja berkurang. Pada kenyataannya, beberapa kasus bunuh diri justru muncul di kalangan pelajar dengan berbagai masalah yang melatarbelakangi tindakan bunuh diri. Wignya, melalui data sebuah harian lokal Bali, menemukan angka bunuh diri di Bali naik dari tahun ke tahun. Wignya mengumpulkan 98 data kasus bunuh diri di Bali pada tahun 2003, kemudian meningkat cukup tajam menjadi 124 kasus pada tahun 2004, 137 kasus pada tahun 2005, dan 145 kasus pada tahun2006. Dalam konteks masyarakat Bali, Wignya melihat fenomena ini disebabkan karena tekanan berlebihan yang dialami seseorang sementara ikatan sosial dan agama merenggang (Vivanews, 2012). Kemanusiaan manusia yang semakin tergerus oleh modernitas dan pendidikan yang tidak banyak membantu bahkan semakin menggerus dan menenggelamkan ini menjadi masalah yang serius. Peran pendidikan perlu dikembalikan kepada hakikinya, yaitu berorientasi kepada kemanusiaan manusia. Permasalahan ini, membangun beberapa pertanyaan yang menjadi latar belakang penelusuran pustaka dan penulisan tulisan ini, yaitu sebagai berikut: 1) Kemanusiaan seperti apa yang menjadi orientasi pendidikan? 2) Pendidikan seperti apa yang memanusiakan manusia?

\section{METODE PENELITIAN}

Menulis mengenai pendidikan yang memanusiakan manusia berarti tak lepas dari pendidikan yang berdasarkan pada keunikan manusia. Tulisan ini berdasarkan penelusuran pustaka melalui kedua pertanyaan latar belakang penelitian sehingga dapat membangun pengetahuan yang memadai dalam menyusun model pendidikan yang memanusiakan manusia yang dapat diuji coba di ruang kelas. Dengan demikian, hal itu dapat membawa angin perubahan pada dunia pendidikan di Indonesia. Studi 
pustaka berikut diawali dengan menelusuri keunikan manusia dalam kemanusiaannya. Kemanusiaan manusia ini menjadi dasar bagi penelusuran pustaka mengenai pendidikan yang memanusiakan.

\section{HASIL DAN PEMBAHASAN}

Mungkin tak banyak orang menyadari bahwa proses pendidikan adalah proses yang menuntut kemampuan seni. Torrance, dikutip oleh Allan C Ornstein mengatakan: "Teaching is perhaps the greatest of the arts because the medium is the human." (1999:15). Mendidik manusia dengan keunikannya sebagai manusia yang bertumbuh dan berkembang tidak hanya secara fisik, juga perasaan, cara berpikir, dan spirit, menuntut pendidikan yang senantiasa juga berkembang baik kurikulum, media belajar, pola ajar, strategi mengajar hingga gaya mengajar. Tiap perubahan menuntut kreativitas dan seni. Sehingga tak berlebihan jika produk pendidikan berupa desain , implementasi dan evaluasi dalam proses pendidikan disebut sebagai karya seni. Paradigma tentang seni dalam pendidikan ini menegaskan bahwa manusia ini unik sehingga perlakuan terhadapnya membutuhkan kemampuan seni. Manusia unik ini tidak saja unik sebagai pribadi, yang berbeda satu manusia dengan manusia lain, juga unik dalam kemanusiaannya yang berbeda dari makhluk ciptaan lainnya.

\section{Manusia yang Sempurna}

Bahasan tentang manusia yang sempurna tidak menuju kepada manusia yang tak bercela dan tanpa cacat. Tak seorangpun manusia tak bercacat cela karenanya, kesempurnaan yang didasarkan pada tak bercacat cela hanyalah utopia belaka yang tak mungkin diraih dan dicapai. Manusia yang bercela itu mengalami kesempurnaan ketika manusia dapat mengembangkan dan mewujudkan kemanusiaan yang justru melalui proses ketidaksempurnaannya sebagai manusia (dalam arti bercacat cela). Kesempurnaan manusia yang bercela itulah yang menjadikan manusia menemukan, mengembangkan, dan mewujudkan kemanusiaan.

\section{Kesempurnaan dalam Kodrat Manusia}

Manusia adalah makhluk yang memiliki kemampuan istimewa. Ia dapat berpikir, bertanya, menyanggah, diam, menyelidiki, berekspresi, marah, bersemangat, berteori, dan banyak hal lain yang dapat dilakukan manusia. Sebagai manusia, wajahnya memerah saat merasa malu atau menahan marah. Kedipan matanya dapat lebih cepat dari biasanya saat ada informasi yang ia sembunyikan. Denyut nadinya dapat lebih cepat saat takut atau marah atau sangat bersemangat. Mengerlingkan matanya saat berpikir sesuatu. Raut wajahnya nampak layu saat tak bersemangat dan tak termotivasi.

Leahy mengemukakan bahwa manusia dengan objektivitasnya, pemikiran, dan kebebasannya, menampilkan diri sebagai suatu pribadi (1984: 28), dan menurutnya hal itu ditunjukkan dalam berbicara. Berbicara adalah penggunaan dinamis-dinamisme dari kodrati manusia. Dalam berbicara, manusia menunjukkan objektivasnya sebagai buah dari proses berpikir. Dalam berbicara manusia menggerakkan bagian dari tubuhnya dan gerakkan itu terjadi karena adanya spirit dalam dirinya untuk berbicara sebagai buah dari kesadaran akan kebebasan. Dalam berbicara, manusia menggunakan perasaannya, ia akan berbicara dengan orang yang ia merasa nyaman berbicara. Sehingga melalui berbicara, manusia menunjukkan kemanusiaannya.

Semua hal yang dapat dilakukan manusia berasal dari anugerah kodrati, pemberian sempurna Pencipta dalam bentuk tubuh, jiwa, pikiran, dan perasaan. Di dalam tubuh, jiwa, pikiran, dan perasaan inilah kesempurnaan manusia tercipta. St. Thomas Aquinas menegaskan bahwa pribadi dengan tubuh, jiwa, pikiran, dan perasaan adalah yang paling sempurna dalam seluruh alam (Leahy, 1984:181). 
Kesempurnaanya ada dalam tubuh, jiwa, pikiran, dan perasaan yang ada dalam diri manusia sebagai pemberian Pencipta sejak awal, mulai dari benih dalam rahim, hingga manusia dilahirkan dan tumbuh berkembang di dalam dunia. Kesempurnaannya ada dalam kodrat kemanusiaannya yang bukan berasal dari manusianya melainkan sebagai anugerah Pencipta.

Plato dengan pemahaman dualismenya, dimana jiwa dan tubuh terpisah, ditolak oleh muridnya sendiri, Aritoteles (Jakarta: 1984, 41) yang memahami bahwa tubuh, jiwa, pikiran, dan perasaan adalah satu. Paham monois yang dibawa oleh Aritoteles ini menjelaskan bahwa kehilangan salah satunya, maka kemanusiaannya/kesempurnaannya tak mewujud. Keempat dimensi, menyatu tak terpisahkan dalam satu pribadi, namun memiliki fungsi yang khas masing-masing dengan cara kerja yang berbeda pula dan cara mewujud yang khas untuk masing-masing. Kehilangan salah satu dari dimensi kemanusiaan, kesempurnaaan manusia memudar demikian juga dengan kemanusiaannya. Kesatuan ini berakibat masing-masing dalam perbedaannya saling terkait, saling terpengaruh dan memengaruhi satu dengan lainnya.

\section{Kesempurnaan dalam Cacat Cela}

Kesempunaan manusia, anugerah Sang Pencipta ini, tidak mengandaikan manusia yang tak bercacat cela. Sebaliknya, kesempurnaan manusia dalam dimensi kemanusiaannya itu eksis di dalam ketidaksempurnaan manusia. Kesempurnaan dalam tubuh yang tidak sempurna, memiliki kelemahan, dapat merasakan sakit, memiliki batas kemampuan dan daya tahan. Kesempurnaan dalam jiwa yang bersemangat penuh gairah dan juga rapuh yang mungkin mati sebelum waktunya. Kesempurnaan dalam perasaan yang dapat marah, sedih, kecewa, gembira. Kesempurnaan dalam pikiran yang dapat memikirkan hal yang membangun dan merusak, pikiran yang mencipta dan menghancurkan.

Kesempurnaan manusia eksis dalam usaha pengembangan keempat dimensi yang justru terbatas dan tak sempurna pengelolaanya dan kesempurnaan manusia membuat ia mampu memilih untuk membuat keputusan apa yang akan ia lakukan. Manusia dapat memilih yang akan ia lakukan dengan dan melalui tubuhnya, jiwanya, pikirannya, dan perasaannya. Akibatnya, melalui pilihannya dalam tumbuh kembang sebagai manusia, manusia dapat saja urung menunjukkan kesempurnaannya, sebaliknya menenggelamkan dan mengubur dalam-dalam. Melalui empat dimensi kemanusiaannya, manusia dapat merusak tubuh, berpikiran negatif dan merusak, tak peduli dengan keselamatan jiwanya, memerangkap dalam pikirannya sendiri dan tak berusaha membebaskan, mengumbar perasaan dalam bentuk emosi negatif. Dengan demikian, lambat laun kemanusiaannya hilang, kesempurnaannya terkubur dalam-dalam entah dimana. Manusia tumbuh menjadi manusia yang bukan manusia yang memakan sesamanya manusia dan memuntahkannya kembali di wajah sesamanya manusia.

Manusia menemukan dan mengembangkan kesempurnaannya sebagai manusia dengan memilih dan bertindak melalui tubuh, jiwa, pikiran, dan perasaan, dimana pilihan dan tindakannya itu justru dapat bercacat cela. Namun, justru dalam cacat cela sebuah pilihan, dan tindakan manusia, melalui tubuh, jiwa, pikiran, dan jiwanya ia mampu berefleksi dari cacat cela membentuk pilihan, keputusan, dan tindakan baru yang membawa manusia menemukan kesempurnaannya. Inilah yang dimaksud dengan istilah kesempurnaan dalam cacat cela. Dan pendidikan berperan aktif menghantar manusia untuk membenamkan kemanusiaannya atau sebaliknya menghantar untuk menemukan, mengembangkan, dan menunjukkan kemanusiaannya.

\section{Pendidikan yang Memanusiakan Manusia}

Memanusiakan manusia berarti menghantar manusia menemukan kesempurnaannya melalui kesadaran pertama-tama akan kesatuan dimensi kemanusiaan, yaitu tubuh, jiwa, pikiran, dan perasaan, juga kesadaran akan kebebasannya sebagai manusia untuk memilih dan bertindak. Melalui 
pembahasan terdahulu mengenai istilah kesempurnaan dalam cacat cela, membuka pemahaman mengenai peran pendidikan dalam membuat cacat cela itu menjadi sebuah batu loncatan menuju kesempurnaan.

Pendidikan yang memanusiakan adalah pendidikan yang mengantarkan manusia pada perkembangan yang signifikan dalam menemukan, mengembangkan, dan menunjukkan kesempurnaan kemanusiaannya. Segala muatan pembelajaran, informasi yang diberikan, serta proses belajar menjadi media yang menantang tubuh, pikiran, jiwa, dan perasaan menemukan dinamikanya dengan seimbang. Di bawah ini dijabarkan penelusuran mengenai peran pendidikan dalam memanusiakan manusia dan pendidikan yang memanusiakan manusia.

\section{Peran Pendidikan dalam Memanusiakan Manusia}

Kesempurnaan manusia yang dianugerahkan Sang Pencipta melalui dimensi kemanusiaan membuat manusia mampu memilih bahkan menciptakan pilihan, dan bertindak sesuai pilihannya. Pendidikan berperan dalam pilihan-pilihan manusia, yaitu kehancuran atau pengembangan kemanusiaan, yang merusak atau membangun, yang mematikan atau memberi kehidupan, yang mencipta atau menghancurkan. Louis, mengutip Levi Strauss, dalam buku manusia sebuah misteri bahwa tujuan terakhir ilmu-ilmu manusia bukan membentuk manusia, melainkan menghancurkannya (1984: 185). Kutipan ini memang dapat dinilai terlalu mengeneralisasi ilmu-ilmu manusia karena tidak semua ilmu menghancurkan kemanusiaan manusia. Namun, tidak berlebihan juga jika kita waspada terhadap keberadaan ilmu-ilmu yang dapat merusak kemanusiaan, ilmu-ilmu yang seakan mencipta tetapi pada kenyataannya menghancurkan, ilmu-ilmu yang berpenampilan apik seakan menolong namun ternyata menjerumuskan. Ilmu-ilmu yang seakan membangun tetapi ternyata menghancurkan kemanusiaan. Belum lagi, strategi mendidik, gaya mendidik, pola didik yang ternyata dapat juga menghancurkan kemanusiaan manusia.

Jika pendidikan berorientasi pada persiapan masa depan dan bukan pada kemanusiaan manusia maka pendidikan dapat menjauhkan manusia dari kemanusiaannya. Tak seorang pun dapat mengetahui dengan jelas dan pasti akan masa depan. Ketidaktahuan ini dapat menyeret manusia pada kekuatiran terus menerus tak berujung hingga ia sendiri kehilangan arah bahkan kehilangan kemanusiaannya. Seorang mahasiswa yang telah meraih kesarjanaannya dengan sangat memuaskan dan lengkap dengan serifikat keahlian yang dapat membuatnya seakan siap menghadapi masa depan, melamar pekerjaan yang sesuai dengan keahliannya. Penantiannya selama berminggu-minggu tak juga berujung pada panggilan dirinya sebagai karyawan sehingga ia putus asa. Ia melihat kembali nilai-nilai yang tertera dalam ijazahnya. Nilai yang sama sekali tidak buruk. Akan tetapi mengapa ia tak juga mendapatkan pekerjaan? Pikirannya mengembara dan kembali ke masa kuliahnya dulu. Teringat perjuangan belajarnya di kampus, tempatnya ditempa berbagai keahlian demi yang namanya masa depan. Dengan putus asa dan kemarahan, akhirnya ia memilih untuk merobek ijazah dengan predikat memuaskan dan sertifikat keahliannya. Baginya, semua usaha kerasnya sia-sia karena ia tak dapat pekerjaan. Ternyata usahanya yang keras demi masa depan tak mendatangkan hasil yang ia harapkan, yaitu bekerja dengan gaji yang menjanjikan. Apa yang ia dengar di bangku kuliah tak sesuai dengan kenyataannya. Ia, yang lulus dengan nilai baik, yang idealnya gampang dapat kerja, sesuai dengan janji para pengajar, ternyata gagal mendapatkan pekerjaan. Jiwanya seakan tak berharga lagi, pikirannya hanya tertuju pada kegagalannya tak mendapatkan pekerjaan, perasaan kecewa, marah, takut menghadapi esok hari menghantuinya. Ia kehilangan arah.

Kisah yang dapat menimpa siapa saja tak terkecuali ini, menunjukkan bahwa pendidikan yang berorientasi pada persiapan masa depan gagal menghantar mahasiswa tersebut menemukan, mengembangkan, dan menunjukkan kemanusiaannya melalui program pendidikan yang ditempuhnya. Bagi mahasiswa yang putus asa tadi, pendidikan hanya sebagai sarana untuk mendapatkan pekerjaan, mendapatkan uang, hidup nyaman, tentram di masa depan tanpa menyadari perkembangan diri dalam dimensi kemanusiaannya melalui pendidikan yang dilaluinya. 
Apa yang keliru dengan pendidikan yang berorientasi pada persiapan masa depan? Masa depan, yang sebenarnya tak ada seorang pun mampu menggambarkannya dengan pasti, hanya mampu menduga berdasarkan pengalaman yang telah dilaluinya itu penuh ketidakpastian (Rose \& Nicholl, 2003: 32). Ketidakpastian yang disebabkan karena kekuatan akan perubahan ini meningkatkan kompleksitas persoalan dan menyusutnya jenis dan lapangan pekerjaan. Sehingga pendidikan yang beroerientasi pada masa depan akan mendidik manusia pada perburuan yang sangat ketat. Hal ini membuat lembaga pendidikan yang hanya berorientasi pada masa depan terjebak hanya melihat hasil dan melupakan proses. Seperti layaknya orang berburu, manusia-manusia berburu dengan sangat ketat mendapatkan targetnya. Satu target menjadi buruan puluhan bahkan ratusan manusia. Membayangkannya, tentu sangat mengerikan sekali. Manusia hanya melihat target tanpa memerhatikan manusia sekelilingnya, sehingga tidak mustahil, karena keterdesakan, manusia memakan sesamanya manusia demi memperkecil persaingan dan memenangkan perburuan berupa target. Saat mendapatkan targetnya ia memakannya namun ia tak puas sehingga ia mulai mengincar target lain dan mulai berburu taget baru. Begitulah manusia menghabiskan waktu hidupnya.

Lembaga pendidikan yang berorientasi hanya pada masa depan juga dapat terjebak dalam dalam bayang-bayang sebuah pertandingan yaitu "to be a number one". Demi memenangkan buruan, jika tidak culas seperti memakan manusia lain sebagai pesaingnya, manusia perlu keahlian yang bukan sekadar bisa melainkan harus menjadi "yang paling” yaitu paling ahli, paling tangkas, paling cepat, paling ahli demi mendapatkan buruan/target. Perbandingan manusia satu dengan manusia lain menjadi sangat kental dalam pendidikan yang hanya berorientasi pada masa depan.

Terjebak pada hasil sebagai nomor satu tanpa mengutamakan proses dan perbandinganperbandingan yang berlebihan dapat membuat manusia manusia yang bertubuh kecil dan berkepala besar. Tubuh kecil karena terlalu banyak beraktivitas, sedikit waktu untuk menikmati makanan dan istirahat. Kepala besar karena memang dilatih untuk selalu berpikir. Perasaan yang nampak kuat dan tangguh namun pada kenyataannya kosong karena tak diperkenankan untuk menjadi lemah dan lembut. Rasa empati terkikis dengan ego kemanusiaanya untuk menjadi pemenang. Jiwa yang rapuh, mudah putus asa dan frustasi karena perbandingan-perbandingan yang terjadi membuatnya merasa kecil tak berarti. Keadaan seperti ini, dimana dimensi kemanusiaan tak berkembang proporsional, membuat manusia bergerak menjauh dari kesempurnaan kemanusiaannya.

Peran pendidikan harus dikembalikan pada hakikatnya, yaitu bukan untuk mempersiapkan masa depan saja tetapi untuk membuat manusia dapat hidup dan melakukan tugas kemanusiaannya, yaitu menemukan, mengembangkan dan menunjukkan kesempurnaannya sebagai manusia. Menemukan, karena kesempurnaan adalah anugerah Sang Pencipta yang telah dimiliki tiap manusia, namun dapat terkubur dalam proses tumbuh kembangnya sebagai manusia. Mengembangkan, karena sebagai manusia, yang bertumbuh dan berkembang tak mencapai perkembangan yang optimal dan proporsional apabila tak diusahakan. Menunjukkan, karena manusia perlu eksis sebagai manusia di antara sesamanya manusia. Dan eksistensinya dalam bentuk manusia yang sempurna dapat mendorong manusia lain juga untuk menemukan, mengembangkan, dan menunjukkan kemanusiaanya. Ketiga hal ini menajdi tugas manusia dalam kehadirannya sabagai manusia di muka bumi ini dan pendidikan menolong manusia menjalankan tugas kemanusiaannya.

\section{Model Pembelajaran yang Memanusiakan Manusia}

Pendidikan yang memanusiakan manusia adalah pendidikan yang berorientasi pada kemanusiaan manusia. Kemanusiaan manusia tercapai melalui pengembangan dimensi kemanusiaan secara seimbang. Pemahaman mengenai kemanusiaan manusia ini menjadi dasar bagi penyusunan model pembelajaran yang berorientasi pada kemanusiaan manusia. Model pembelajaran dibangun dalam ruang-ruang yang mefasilitasi pembelajar untuk mengembangkan dimensi kemanusiaan, yaitu tubuh, jiwa, pikiran, dan perasaan. 
Kata perkembangan seyogyanya menjadi kata kunci dalam pendidikan. Melalui kesempurnaan yang dianugerahkan Sang Pencipta, yaitu dimensi kemanusiaan, perkembangan manusia menjadi sangat unik dan berbeda dari makhluk lainnya. Perkembangan manusia meliputi perkembangan tubuh, jiwa, pikiran, dan perasaannya. Perkembangan manusia, selain dipengaruhi oleh potensi tumbuh kembang yang dibawanya sejak lahir juga oleh perlakuan lingkungan terhadapnya. Walaupun beberapa ahli mengembangkan pengukuran perkembangan ini namun sesungguhnya tidak ada yang mampu mengukur secara utuh potensi tumbuh kembang ini karena manusia adalah misteri. Leavy mengutip Foucalt dalam bukunya Les Mats Et Les Choses, yang mengatakan bahwa Manusia melebihi semua macam komprehensi maka ia harus menolak segala definisi yang mau menempatkannya dalam suatu esensi (1984:190). Potensi tumbuh kembang ini selalu menjadi misteri, sehingga perlakuan lingkungan memiliki peran sangat besar bagi manusia mengalami tumbuh kembang yang maksimal.

Covey, dalam buku “The $8^{\text {th }}$ Habit, Melampaui Efektivitas, Menggapai Keagungan”, menguraikan pengembangan dimensi kemanusiaan ini melalui kecerdasan yang menyertai tiap dimensi (2005:74). Ia menguraikan kecerdasan yang disebutnya sebagai anugerah bawaan tiap dimensi, sesuai dengan gambar 2 .

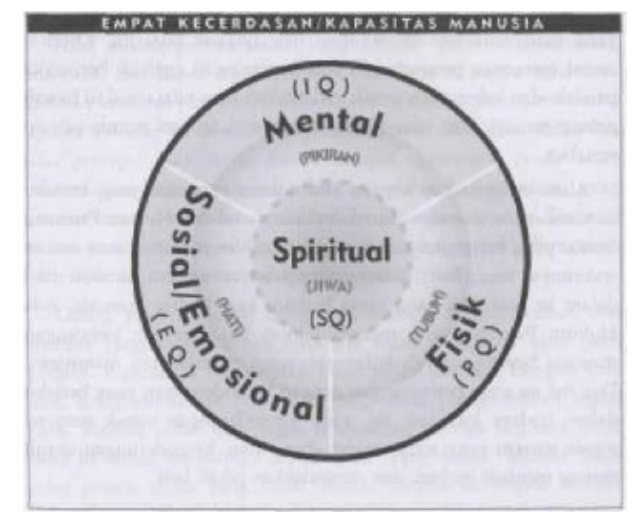

Gambar 2 Empat Kecerdasan Anugerah Bawaan Manusia (Covey, 2005: 74)

Melalui perkembangan tiap kecerdasan inilah dimensi kemanusiaan mengalami perkembangan. Setiap usaha pengembangan harus ada arah perkembangannya agar pengembangan menjadi bermakna bagi kemanussian dan tidak salah arah. Untuk ini, Covey (2005: 96) menolong penentuan arah pengembangan dimensi kemanusiaan melalui perwujudan tertinggi tiap kecerdasan. Perwujudan tertinggi ini dapat menjadi arah bagi pengembangan dimensi kemanusiaan.

Pertama, perkembangan pikiran. Perwujudan tertinggi dalam pengembangan pikiran, menurut Stephen Covey adalah visi. Visi adalah hasil dari pikiran yang menjembatani antara kebutuhan dengan kemungkinan kemungkinan. Samples, dalam bukunya Revolusi Belajar, setuju dengan pemikiran Fuller yang menggambarkan bahwa pikiran manusia adalah pikiran dengan sistem terbuka (2002: 43). Ironisnya, pendidikan tak menyadari bahwa didikannya yang berupa indoktrinasi merupakan sistem tertutup sehingga pikiran berkembang sangat terbatas yang sulit menghasilkan karya yang kreatif. Sedangkan visi, adalah hasil dari pikiran terbuka. Di dalam visi, segala hal yang tak mungkin menjadi mungkin. Karya kreatif tercipta melalui visi. Visi terwujud dari manusia yang berpikir di luar kotak. Visi memampukan kita melihat apa yang terlihat (tindakan orang lain) dan berkaitan dengan segala kemungkinan. Visi menolong kita dapat memisahkan antara tindakan dan sebagai pribadi. Pemisahan ini membuat kita dapat memperlakukan seseorang tanpa syarat, tanpa dipengaruhi oleh stimulus yang tercipta dari perlakuannya terhadap kita. Kita mampu memaafkan walaupun telah berkali-kali ia melukai kita karena kita mampu melihat kebutuhan nya untuk dimaafkan. Kita mampu mengasihi 
setelah berulang kali dikhianati karena kita mampu melihat kebutuhannya untuk dicintai. Kita mampu menerimanya tanpa mendasari pada perlakukannya kepada kita.

Pendidikan yang memberi ruang bagi pengembangan pikiran, adalah pendidikan yang menciptakan visi dalam diri setiap naradidiknya. Bukan sekadar ia dapat menyelesaikan persoalan, lebih dari itu menolong naradidik meraih visi dalam menyelesaikan persoalan. Di kelas, seorang guru yang memberi masalah kepada naradidiknya tidak sekadar memberi masalah dan bagaimana pemecahannya, lebih dari itu yaitu mengajak nara didiknya menciptakan visi melalui persoalan yang akan dipecahkan. Menciptakan visi dapat dilakukan dengan menantang atau mengarahkan naradidik sesuai dengan jenjangnya, untuk dapat menjawab mengapa saya harus memecahkan persoalan ini, mengapa saya harus belajar topik ini, mengapa saya harus menghafal, mengapa saya harus mengerjakan pekerjaan rumah, mengapa saya harus mengumpulkan tugas tepat waktu, mengapa saya harus berusaha sebaik-baiknya dalam mengerjakan tugas.

Kedua, perkembangan tubuh. Perwujudan tertinggi dalam pengembangan tubuh, menurut Covey adalah disiplin. Disiplin ini muncul saat visi bertemu dengan komitmen, suatu kekuatan kehendak yang diwujudkan dalam tindakan. Di dalam disiplin selalu ada pengorbanan. Namun, tanpa disiplin mustahil visi dapat terwujud. Disiplin menentukan realitas dan menerimanya. Melalui kedisplinan, seseorang akan mengalami keadaan yang benar-benar bebas. Hal ini kebalikan dari pemikiran banyak orang bahwa kedisiplinan itu menjerat dan memenjara, sebaliknya justru kedisiplinan membuat kita memiliki kebebasan. Covey memakai ilustrasi seorang anak yang disiplin berlatih piano, membuat ia dapat bermain piano. Keahliannya dalam bermain piano ini memberikan kebebasan bagi dia untuk dapat memainkan alat musik piano. Sebaliknya, orang yang tak dapat memainkan piano, baginya pilihan lebih sempit, tak ada pilihan untuk bermain piano karena memang ia tidak menguasainya. Contoh lain, seseorang yang disiplin menabung dapat lebih bebeas menggunakan uangnya karena ia memliki uang lebih banyak di tabungannya ketimbang orang yang tidak disiplin menabung. Pemahaman mengenai kedisiplinan yang membebaskan inilah yang perlu ditanamkan.

Pendidikan yang memberi ruang bagi perkembangan tubuh tidak hanya puas diri dengan memasukkan pelajaran olah raga. Perkembangan tubuh tidak akan tercapai hanya melalui pelajaran olah raga yang berorientasi pada keahlian raga saja. Mengacu pada pemikiran covey, maka pendidikan yang memberi ruang bagi perkembangan tubuh adalah pendidikan yang menanamkan kedisiplinan yang membebaskan, terintegrasi dalam setiap pelajaran. Kata kedisiplinan yang membebaskan ini tidak berarti ada kedisiplinan yang tidak membebaskan. Pada dasarnya kedisiplinan itu membebaskan. Namun, pemahaman yang keliru tentang kedisiplinan yang memenjarakan dan membatasi ruang gerak inilah, menjadikan kata membebaskan penting untuk dikaitkan dengan kedisiplinan. Di kelas, seorang guru yang menanamkan kedisiplinan tidak hanya menuntut untuk tepat waktu saja, tetapi juga mengarahkan nara didik untuk melihat kebebasan yang dapat ia raih jika ia tepat waktu. Tidak melulu kedisiplinan dikaitkan dengan hukuman karena kedisiplinan yang dikaitkan melulu dengan hukuman akan menimbulkan pemahaman yang keliru tentang kedisiplinan. Berbicara kedisilinan tidak hanya berbicara mengenai tepat waktu tetapi juga kebebasan yang akan diraih ketika kita disiplin. Konsep tentang disiplin yang benar inilah yang akan menolong nara didik mengembangkan tubuhnya hingga mencapai perwujudan tertinggi, yaitu menjadi manusia yang disiplin.

Ketiga, perkembangan perasaan. Perwujudan tertinggi dalam pengembangan perasaan, menurut Stephen Covey adalah gairah. Gairah adalah api mempertahankan disiplin dan terus berjuang menggapai visi. Gairah ini muncul saat kebutuhan bertemu dengan keunikan bakat kita. Dengan demikian penting sekali untuk mengetahui bakat kita. Seseorang yang mengerjakan keahliannya yang bukan bakatnya perlu di motivasi terus menerus dari luar, berbeda dengan orang yang melakukan keahliannya yang memang bakatnya, maka api itu sudah ada di dalam dirinya tak perlu dicari lagi. 
Pendidikan yang memberi ruang bagi perkembangan perasaan adalah pendidikan yang memerhatikan gairah nara didiknya. Pendidikan tidak hanya indoktrinasi pengetahuan atau sekadar meraih prestasi dalam bentuk piala dan penghargaan dan mengabaikan gairah belajar. Gairah ini sangat labil, sangat bergantung pada situasi. Gairah muncul sebagai respon dari situasi. Pendidikan yang memerhatikan gairah berarti juga memerhatikan sitausi dimana pendidikan itu berlangsung. Di kelas, seorang guru perlu memerhatikan lingkungan belajar, baik yang berupa fasilitas maupun lingkungan yang sengaja diciptakan menciptakan gairah di dalam diri naradidiknya. Hal ini tentu lebih mudah dituliskan dan dibicarakan ketimbang dilakukan, karena di dalam diri guru pun ada gairah itu. Sulitnya, gairah itu cepat sekali menular, membuat guru, sebagai pelakon dalam dunia pendidikan, perlu terlebih dahulu menciptakan gairah dalam mengajar dan belajar yang akan ia tularkan di kelas kepada nara didiknya. Pengalaman sang guru dalam menciptakan gairah untuk belajar dan mengajar ini menjadi modal awal untuk pertama-tama berempati kepada naradidik yang gairahnya menurun. Juga menjadi modal bagi sang guru untuk mengarahkan naradidiknya menciptakan gairah di dalam diri masing-masing dalam menghadapi berbagai situasi.

Keempat, perkembangan jiwa. Perwujudan tertinggi dalam pengembangan jiwa, menurut Covey adalah nurani. Orang sering menyebutnya dengan suara hati, suara Tuhan, yang adalah kesadaran moral yang universal, terlepas dari agama, budaya, geografis, nasionalitas, dan ras tertentu, mengenai apa yang baik dan buruk dan dorongan untuk memberi makna serta member sumbangan nyata. Penyingkapan nurani ini justru saat kita berada dalam keragaman. Nurani sebagai perangkat nilai, yaitu kesadaran mengenai keadilan, kejujuran, rasa hormat, kepercayaan, cinta. Nurani kebalikannya dari ego. Nurani adalah suara lembut dan pelan dalam batin kita sedangkan ego, bersifat tiran, kejam, senang memaksakan kehendak, memfokuskan pada diri sendiri dan kesenangan diri sendiri. Ego mengklasifikasikan, melihat hubungan dengan kaca mata ancaman dan bukan. Sedangkan nurani, mengantarkan pada pemahaman yang lebih luas dan inklusi. Nurani memandang kehidupan dalam kecamata pelayanan dan pemberian, fokusnya adalah keamanan dan kepenuhan orang lain. Ego bekerja saat menghadapi kritis, tetapi tidak memiliki pertimbangan mendalam sedangkan nurani dipenuhi pertimbangan sehingga memiliki khazanah jawaban yang banyak. Ego merasa terancam dengan kritikan, sebaliknya nurani mampu belajar dari sebuah kesalahan dan kritikan. Nurani rela berkorban, mengalahkan diri sendiri, menundukkan ego demi tujuan atau prinsip yang lebih tinggi/mulai. Nurani tidak memisahkan visi dan cara mencapainya. Tujuan sudah ada dalam cara mencapainya. Nurani terus menerus mengingatkan kita ikatan antara tujuan dan cara mencapainya dan bahwa keduanya tak dapat dipisahkan.

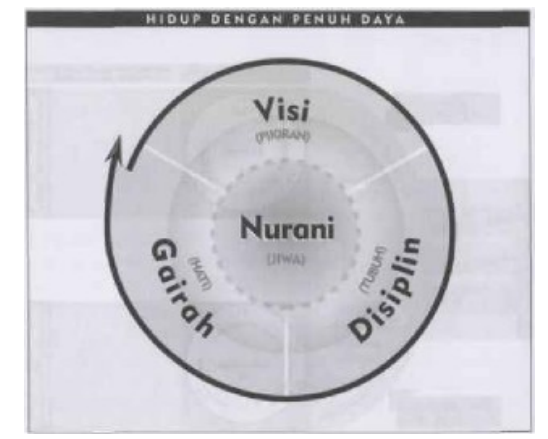

Gambar 3 Perwujudan dari Pengembangan Dimensi Manusia

(Covey, 2005:96)

Dimensi kemanusiaan yang menyatu, nampak dalam perwujudan pengembangan tiap dimensi. Nurani adalah alasan bagi perwujudan visi, disiplin, dan gairah, sedangkan visi mengidentifikasi dalam apa yang akan diwujudkan, disiplin dalam bagaimana cara mencapainya. Gairah adalah api 
dibalik mengapa, apa, dan bagaimana tadi. Menurut Covey, nurani akan membangkitkan integritas dan ketenangan pikiran.

Pendidikan yang memberi ruang bagi perkembangan jiwa adalah pendidikan yang mengajak anak mengembangkan nuraninya. Ini hanya mungkin diraih jika pendidikan dibangun di dalam ruang kebebasan. Ruang kebebasan ini adalah ruang yang bebas dari perasaan takut salah, bebas dari tekanan otoritas, bebas menentukan pilihan dan bertindak. Ruang ini adalah ruang kebebasan yang bukan tanpa batas tetapi ruang yang memungkinkan nurani setiap individu di dalamnya muncul. Di dalam ruang kebebasan, tidak ada pelabelan orang salah dan orang benar, tindakan yang salah dianggap sebagai fakta perilaku dan tak membuat si pembuat kesalahan menjadi manusia yang salah. Kesalahan dianggap sebagai bagian dari pengembangan diri. Semua manusia memiliki hak berbicara tak terkecuali dan tak dibedakan berdasarkan jabatan dan usia. Pilihan-pilihan selalu tersedia dan setiap orang berhak memilih dengan menanggung setiap konsekuensi atas pilihan dan tindakannya. Di dalam ruang kebebasan ini ada ruang refleksi sebagai pribadi maupun kelompok. Setiap tindakan dan pilihan di refleksikan dengan pengembangan dimensi kemanusiaan sehingga segala perubahan atau pengembangan baik pilihan maupun tindakan berasal dari hasil refleksi. Proses refleksi di sini adalah proses melihat kembali pilihan dan tindakan dengan segala konsekuensi yang menyertainya dan mengkritisi pilihan atau tindakan sebagai bagian dari perwujudan dimensi kemanusiaan. Ruang refleksi ini membatasi ruang kebebasan tidak menjadi kebebasan yang brutal.

Melalui penelusuran perkembangan dimensi kemanusiaan ini, maka dapat tercipta model pendidikan yang memanusiakan manusia menjadi dasar bagi pengembangan desain, implementasi, serta evaluasi dalam proses pendidikan sebagai berikut.

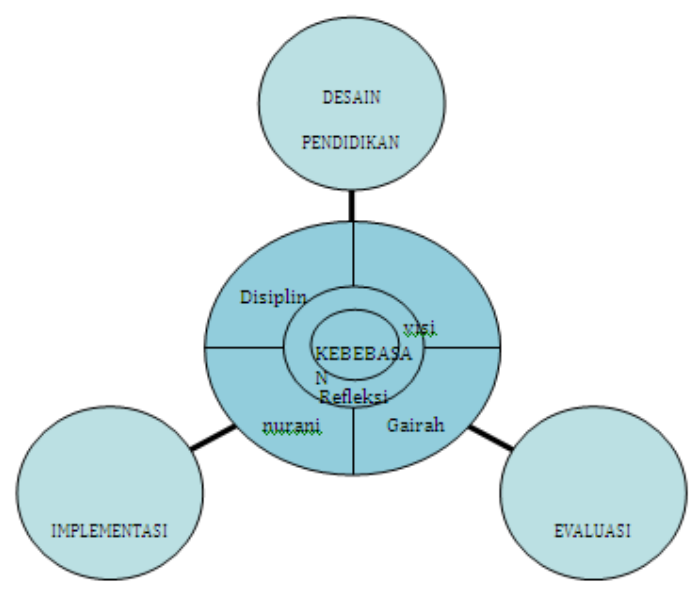

Gambar 4 Model Pendidikan yang Memanusiakan Manusia

Desain pendidikan berupa kurikulum diimplementasikan dan dievaluasi dengan memerhatikan perkembangan dimensi kemanusiaan, yaitu pikiran, tubuh, perasaan, dan jiwa. Perkembangan tiap dimensi menuju pada perwujudan visi, disiplin, gairah, dan nurani. Perwujudan ini dimungkinkan terwujud dalam ruang refleksi dimana di dalamnya ada ruang kebebasan.

Model pendidikan yang memanusiakan manusia ini sangat mungkin diaplikasikan sehingga layak untuk diuji coba di laboratorium penelitian, ruang-ruang kelas. Melakukan uji coba ini memang memerlukan keberanian karena ada perombakan paradigma mengenai manusia, kesempurnaan manusia, dan peran pendidikan manusia. Keberhasilan tidak dilihat dari prestasi akademik, yang akan menimbulkan kemurungan klinik bagi sebagian manusia didik yang kesulitan mencapainya, tetapi dilihat dari usaha menemukan, mengembangkan, dan mewujudkan kemanusiaannya. 


\section{SIMPULAN}

Kemanusiaan yang menjadi orientasi pendidikan adalah manusia yang menemukan, mengembangkan, dan mewujudkan anugerah kodratinya berupa dimensi yang berbeda tetapi satu, yaitu tubuh, jiwa, pikiran, dan perasaan melalui kegiatan memilih, bertindak, dan berefleksi. Perwujudan tertinggi yang menjadi arah pengembangan dimensi kemanusiaan sekalian menjadi acuan dalam evaluasi pendidikan adalah terwujudnya visi, kedisiplinan, gairah, dan nurani dalam diri nara didik. Pendidikan yang memanusiakan manusia adalah pendidikan yang memberi ruang bagi pengembangan dimensi kemanusiaan, ruang kebebasan, dan ruang berefleksi dengan model sebagai berikut.

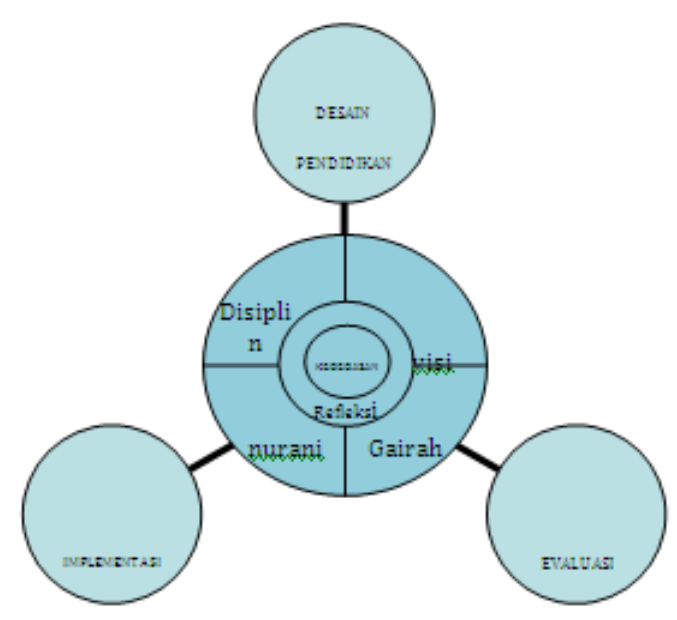

\section{Saran}

Bagi penyelenggara pendidikan, disarankan agar pendidikan yang diselenggarakan menolong nara didik untuk menciptakan visi, membangun kedisiplinan diri melalui konsep kedisiplinan yang membebaskan, gairah belajar yang membara di hati nara didik, dan kemampuan mendengarkan dan mempertajam suara hati sebagai biduk dalam mengarungi gelombang kehidupan. Untuk ini beberapa hal yang perlu diperhatikan oleh penyelenggara pendidikan, yaitu: mengajak naradidik menemukan sebuah visi dalam setiap program pembelajaran dan proses pembelajaran; membangun konsep kedisiplinan yang membebaskan dengan tidak melulu mengaitkan kedisiplinan dengan hukuman melainkan memperlihatkan ikatan yang erat antara visi dan kedisiplinan yang pada akhirnya, jika visi tercapai maka kebebasan sejati akan diraih; membangun sitausi belajar yang meningkatkan gairah belajar; menciptakan ruang belajar yang bebas untuk mengungkapkan diri, mengekspresikan konsep berpikir, tak dibatasi pembedaan gender, jabatan, otoritas, status sosial ekonomi, kecerdasan, sikap, dan nilai ujian dan menghantar pada sebuah proses refleksi.

Bagi pemerhati pendidikan, disarankan agar menguji coba model pendidikan kemanusiaan ini sebagai upayanya menciptakan pendidikan yang mengembangkan dimensi kemanusiaan manusia. 


\section{DAFTAR PUSTAKA}

Berk, L. E. (1989). Child development. USA: Allyn and Bacon.

Brooks, J. G., \& Brooks, M. G. (1993). In search of understanding the case for constructivist classrooms. Virginia: The Association for Supervision and Curriculum Development.

Covey, S. R. (2005). The 8 th habit melampaui efektivitas, menggapai keagungan. Jakarta: Gramedia Pustaka Utama.

Freire, P., \& Faunendez, A. (1995). Belajar bertanya, pendidikan yang membebaskan. Jakarta: BPK Gunung Mulia.

Fruth, H. G. (1970). Piaget for teacher. New York: Prentice Hall.

Gardner, H. (2007). Five minds for the future. Jakarta: Gramedia Pustaka Utama.

http://id.wikipedia.org/wiki/Berkas:Suicide rates map-en.svg, 24 Agustus 2012

http://myais.fsktm.um.edu.my/6578/1/JPPSee_(113-129)B.pdf, 26 Agustus 2012

http://sorot.vivanews.com/news/read/114847-pulung_gantung_gunungkidul, 20 Desember 2012

http://www.bps.go.id/, 23 Desember 2011

Hyde, A. A., \& Bizar, M. (1989). Thingking in Context, Teaching Cognitive Processes Across the Elementary School Curriculum. New York: Longman.

Kosslyn, S. M., \& Rosenberg, R. S. (2000). Psychology, the Brain, the Person, the World. Boston: Allyn \& Bacon, A Pearson Education.

Leahy, L. (1984). Manusia, Sebuah Misteri Sintesa Filosofis tentang Makhluk Paradoksal. Jakarta: Gramedia.

Lewis, R. G., dan Smith, D. H. (1994). Total Quality in Higher Education. USA: St Lucie Press.

Ornstein, A. C. (1999). Strategies for Efective Teaching. New York: Mc Graw Hill.

Palmer, P. J. (1990). The active life. San Fransisco: Jossey-Bass.

Reiser, R. A., \& Dempsey, J. V. (2002). Trends and Issues in Instrustional Design and Technology. New Jersey: Merril Prentice Hall.

Rose, C. \& Nicholl, M. J. (2003). Accelerated Learning for the $21^{\text {st }}$ Century, Cara Belajar Cepat Abad $X X I$. Bandung: Nuansa.

Samples, B. (2002). Revolusi Belajar untuk Anak. Bandung: Kaifa.

Slavin, R. E. (1991). Eucational psychology third edition. USA: Allyn and Bacon . 